\title{
Developmental Regulation of GLUT-1 (Erythroid/Hep G2) and GLUT-4 (Muscle/Fat) Glucose Transporter Expression in Rat Heart, Skeletal Muscle, and Brown Adipose Tissue*
}

\author{
T. SANTAluCíA, M. CAMPS, A. CASTElló, P. MUÑoZ, A. NUEL, X. TESTAR, \\ M. PALACIN AND A. ZORZANO \\ Departament de Bioquímica i Fisiologia, Facultat de Biologia, Universitat de Barcelona, \\ 08028 Barcelona, Spain
}

\begin{abstract}
The expression of GLUT-1 (erythroid/Hep G2) and GLUT-4 (muscle/fat) glucose transporters was assessed during development in rat heart, skeletal muscle, and brown adipose tissue. GLUT-4 protein expression was detectable in fetal heart by day 21 of pregnancy; it increased progressively after birth, attaining levels close to those of adults at day 15 post natal. In contrast, GLUT-4 messenger RNA (mRNA) was already present in hearts from 17 day-old fetuses. GLUT-4 mRNA stayed low during early postnatal life in heart and brown adipose tissue and only increased after day 10 post natal. The expression pattern for GLUT-4 protein in skeletal muscle during development was comparable to that observed in heart. In con trast to heart and skeletal muscle, GLUT-4 protein in brown adipose tissue was detected in high levels ( $30 \%$ of adult) during late fetal life.

During fetal life, GLUT-1 presented a very high expression level in brown adipose tissue, heart, and skeletal muscle. Soon after birth, GLUT-1 protein diminished progressively, attaining adult levels at day 10 in heart and skeletal muscle. GLUT-1 mRNA levels in heart followed a similar pattern to the GLUT1 protein, being very high during fetal life and decreasing early in post natal life. GLUT-1 protein showed a complex pattern in brown adipose tissue: fetal levels were high, decreased after birth, and increased subsequently in post natal life, reaching a peak
\end{abstract}

by day 9 .

Progesterone-induced postmaturity protected against the decrease in GLUT-1 protein associated with post natal life in skeletal muscle and brown adipose tissue. However, GLUT-4 induction was not blocked by postmaturity in any of the tissues subjected to study.

These results indicate that: 1) during fetal and early post natal life, GLUT-1 is a predominant glucose transporter isotype expressed in heart, skeletal muscle, and brown adipose tissue; 2) during early post natal life there is a generalized GLUT-1 repression; 3 ) during development, there is a close correlation between protein and mRNA levels for GLUT-1, and therefore regulation at a pretranslational level plays a major regulatory role; 4) the onset of GLUT-4 protein induction occurs between days 20-21 of fetal life; based on data obtained in rat heart and brown adipose tissue, there is a dissociation during development between mRNA and protein levels for GLUT-4, suggesting modifications at translational or posttranslational steps; and 5) postmaturity blocks the decrease in GLUT-1 expression but not the induction of GLUT-4. observed soon after birth. All these findings suggest that GLUT-1 repression and GLUT-4 induction are mediated by different mechanisms. (Endocrinology 130: $837-846,1992)$
G LUCOSE transport by facilitated diffusion is expressed in virtually all mammalian cells. Recent studies have established that this process is mediated, in mammalian cells, by a family of related glucose transport proteins. So far, five different complementary DNAs

Received July 3, 1991.

Address all correspondence and requests for reprints to: Dr. Antonio Zorzano, Departament de Bioquímica i Fisiologia, Facultat de Biologia, Universitat de Barcelona, Avinguda Diagonal 645, 08028 Barcelona, Spain.

* This work was supported in part by Dirección General de Investigación Cientifica y Técnica Research Grant PB89/0331, Fondo de Investigaciones Sanitarias Grant 89/0174, a grant from the Juvenile Diabetes Foundation International, pre-doctoral fellowships from the Ministerio de Educación y Ciencia (to T.S., M.C., and A.C.), and a grant from the Fondo de Investigaciones Sanitarias (to P.M.).
(cDNAs) encoding these different species have been isolated (1-11), which have been named GLUT-1 (erythroid/Hep G2), GLUT-2 (liver), GLUT-3 (brain), GLUT4 (muscle/fat), and GLUT-5 (small intestine). These proteins exhibit considerable homology in their primary sequences, but differ in their biochemical properties and tissue distribution $(3,5,11-14)$.

Insulin causes a rapid stimulation of glucose transport in brown and white adipose tissue, heart, and skeletal muscle, the only tissues that express type GLUT-4 glucose transporters $(6-10,13)$. Nevertheless, these tissues also express GLUT-1 isotype (15-17), although, hased on studies performed with isolated rat adipocytes, GLUT -4 represents $90 \%$ of the total glucose transporters expressed in this cell type (18). In spite of the large 
differences in absolute expression, both carriers play relevant roles in respect to the cell economy of glucose. Thus, under basal conditions, glucose transport is maintained by the activity of GLUT-1 transporters present in the plasma membrane. However, after stimulation with insulin, the GLUT-4 isotype becomes the major glucose transporter in this membrane (18). In this regard, insulin plays a complex role in the regulation of glucose transport, since on one hand, it causes a rapid translocation of GLUT-4 carriers in isolated adipocytes and, on the other hand, it seems to be required to maintain GLUT-4 transporter expression, so adipocytes from diabetic or starved animals show a marked depletion of GLUT-4 transporters (19-22), concomitant with a substantial decrease in the effect of insulin-stimulating glucose transport (23-26).

Regarding the development of the effect of insulin on glucose uptake by insulin-sensitive tissues, it is known that during fetal life, tissues such as heart or diaphragm have a high rate of glucose use $(27,28)$, which is greater than in adult tissue. In addition, it has been reported that fetal heart responds to insulin-increasing glucose transport (27), and that the effect of insulin on glucose transport in the diaphragm increases markedly during post natal life (28), showing no correlation with the total size of intracellular glucose transporters, as assessed by cytochalasin B binding (28). However, there is a lack of information regarding the developmental regulation of glucose transporter expression in insulin-sensitive tissues. Therefore, in this report we have investigated the expression of GLUT-1 and GLUT-4 in heart, skeletal muscle, and brown adipose tissue during development in the rat. Here, we describe the high expression of GLUT-1 during fetal life and the post natal acquisition of GLUT-4.

\section{Materials and Methods}

\section{Materials}

$\left[{ }^{125} \mathrm{I}\right]$ Goat anti-mouse immunoglobulin $\mathrm{G}$ and $\left[{ }^{125} \mathrm{I}\right]$ protein $\mathrm{A}$ were purchased from Amersham (Amersham, UK). Hybond N was from Amersham and random priming DNA labeling kit from Boehringer (Mannheim, Germany). Immobilon was obtained from Millipore (Bedford, MA). All electrophoresis reagents and mol wt markers were obtained from Bio-Rad (Richmond, CA). $\gamma$-Globulin and most commonly used chemicals were from Sigma (St. Louis, MO).

\section{Animals and tissue sampling}

Female Wistar rats (150-200 g) obtained from our own colony were mated, and gestation was timed from the appearance of spermatozoids in vaginal smears. The rats were fed with Purina laboratory chow ad libitum and housed in animal quarters maintained at $22 \mathrm{C}$ with a 12 -h light, 12 -h dark cycle. At different gestational times (17-21 days), mothers were an- esthetized with sodium pentobarbital (5-7 mg/100 g body wt). Fetuses were removed, and interscapular brown adipose tissue, heart, and skeletal muscle (hindlimbs) were rapidly collected and frozen in liquid nitrogen. When the post natal period was studied, pups remained with their mother after delivery and were anesthetized with sodium pentobarbital at different times before tissue sampling.

Postmature fetuses were obtained on day 23 from pregnant rats treated daily with $7 \mathrm{mg}$ progesterone $(35 \mathrm{mg} / \mathrm{ml}$ ricine oil) from day 20 of pregnancy (29). Control pregnant rats received equal volumes of ricine oil, and their pups were studied 3 days later (day 1 post natal).

\section{Preparation of membrane fractions from tissues}

Tissues were homogenized in $10 \mathrm{vol}$ ice-cold buffer containing $25 \mathrm{~mm}$ HEPES, $250 \mathrm{~mm}$ sucrose, $4 \mathrm{~mm}$ EDTA, 1 trypsin inhibitor unit/ml aprotinin, $25 \mathrm{mM}$ benzamidine, $0.2 \mathrm{mM}$ phenylmethylsulfonylfluoride, $1 \mu \mathrm{M}$ leupeptin, and $1 \mu \mathrm{M}$ pepstatin, $\mathrm{pH}$ 7.4. Homogenates from brown adipose tissue and heart were centrifuged at $5,000 \times \mathrm{g}$ for $5 \mathrm{~min}$ at $4 \mathrm{C}$. The supernatant was then centrifuged at $150,000 \times g$ for $2 \mathrm{~h}$ at $4 \mathrm{C}$ to obtain the membrane fractions. The homogenates from skeletal muscle were centrifuged at $15,000 \times g$ for $20 \mathrm{~min}$ at $4 \mathrm{C}$. The supernatants were adjusted to $0.8 \mathrm{M} \mathrm{KCl}$, incubated at $4 \mathrm{C}$ for 30 $\mathrm{min}$, and then centrifuged for $90 \mathrm{~min}$ at $200,000 \times \mathrm{g}$ at $4 \mathrm{C}$ to obtain the membranes. The membrane pellets were resuspended in homogenization buffer and repeatedly passed through a 25 -gauge needle before storage at $-20 \mathrm{C}$. Proteins were measured by the method of Bradford (30) using $\gamma$-globulin as a standard.

\section{Electrophoresis and immunoblotting of membranes}

Sodium dodecyl sulfate (SDS)-polyacrylamide gel electrophoresis was performed on membrane protein in accordance with the method of Laemmli (31). Proteins were transferred to Immobilon as previously reported (18) in buffer consisting of $20 \%$ methanol, $200 \mathrm{~mm}$ glycine, $25 \mathrm{~mm}$ Tris, $\mathrm{pH}$ 8.3. After transfer, the filters were blocked with $5 \%$ nonfat dry milk, $0.02 \%$ sodium azide in PBS for $1 \mathrm{~h}$ at $37 \mathrm{C}$ and were incubated with antibodies. Transfer was confirmed by Coomassie blue staining of the gel after the electroblot. Antibody 1F8 purified by protein A chromatography (kindly donated by Dr. Paul F. Pilch, Boston University, Boston, MA) was used at $5-10 \mu \mathrm{g} / \mathrm{ml}$ in $1 \%$ nonfat dry milk, $0.02 \%$ sodium azide in PBS for $1 \mathrm{~h}$ at $37 \mathrm{C}$, to immunoblot GLUT-4. Detection of antibody-antigen complexes was effected with goat antimouse $\left[{ }^{125} \mathrm{I}\right]$ antibody and autoradiography. Rabbit $\mathrm{Bb}$ antiserum raised against the purified human erythrocyte glucose transporter (a gift of Dr. Christin Carter-Su, University of Michigan, Ann Arbor, MI) was used directly at a 1:400 dilution and was incubated with transferred protein overnight at room temperature in $1 \%$ nonfat dry milk, $0.02 \%$ sodium azide in PBS. Detection of the immune complex with the rabbit antibody was accomplished using $\left[{ }^{125} \mathrm{I}\right]$ protein $\mathrm{A}$ for $4 \mathrm{~h}$ at room temperature. The autoradiograms were quantified using scanning densitometry. Immunoblots were performed under conditions where autoradiographic detection was in the linear response range. 


\section{$R N A$ isolation and Northern blot analysis}

Total RNA from heart was extracted using the acid guanidinium isothiocyanate/phenol/chloroform method as described by Chomczynski and Sacchi (32). All samples had a 260/280 absorbance ratio over 1.7 .

After quantification, total RNA $(15 \mu \mathrm{g})$ was denatured at 65 $\mathrm{C}$ in the presence of formamide, formaldehyde, and ethidium bromide (33) to allow the visualization of RNA. RNA was separated on a $1.2 \%$ agarose/formaldehyde gel and blotted on Hybond $\mathrm{N}$ filters. The RNA in gels and in filters was visualized with ethidium bromide and photographed by UV transillumination to ensure the integrity of RNA, to check the loading of equivalent amounts of total RNA, and to confirm proper transfer. RNA was transferred in $10 \times$ standard saline citrate (SSC; $0.15 \mathrm{M} \mathrm{NaCl}$ and $0.015 \mathrm{M}$ sodium citrate, $\mathrm{pH} 7.0$ ).

Blots were initially prehybridized for $4 \mathrm{~h}$ at $45 \mathrm{C}$ in $50 \%$ formamide, $5 \times$ Denhardt's $(1 \times$ Denhardt's solution is $0.02 \%$ polyvinylpyrolidone, $0.02 \%$ Ficoll, $0.02 \%$ BSA), $0.5 \%$ SDS, $5 \times$ SSPE $(1 \times$ SSPE is $0.15 \mathrm{M} \mathrm{NaCl}, 1 \mathrm{~mm}$ EDTA, and $10 \mathrm{~mm}$ $\mathrm{NaH}_{2} \mathrm{PO}_{4}, \mathrm{pH} 7.4$ ), and $0.5 \mathrm{mg}$ denatured salmon sperm DNA. The blots were then hybridized to the corresponding probes for $12 \mathrm{~h}$ at $42 \mathrm{C}$ in $50 \%$ formamide, $5 \times$ Denhardt's, $0.05 \%$ SDS, 5 $\times$ SSPE, $10 \%$ dextran sulfate, and $0.5 \mathrm{mg}$ denatured salmon sperm DNA. The cDNA probe for GLUT-1 is a 1346-base pair EcoRI fragment and the cDNA probe for GLUT-4 is a 2007base pair SalI fragment. Both cDNA probes were obtained from Dr. Graeme I Bell (University of Chicago). The cDNA probes were labeled with $\left[{ }^{32} \mathrm{P}\right]$ cytidine triphosphate by random oligonucleotide priming. The probes were included at $1.5 \times 10^{6} \mathrm{cpm} /$ $\mathrm{ml}$. Filters were washed for $15 \mathrm{~min}$ in $2 \times \mathrm{SSC}$ at room temperature, and then twice in $0.4 \times \mathrm{SSC}, 0.1 \%$ SDS (first wash for $20 \mathrm{~min}$ and second wash for $30 \mathrm{~min}$ ) at $55 \mathrm{C}$. The abundance of specific glucose transporter message was quantitated by scanning densitometry of autoradiograms as described above.

\section{Results}

Expression of mRNA and protein levels of GLUT-A and GLUT-1 glucose transporters in rat heart during development

The expression of GLUT-1 and GLUT-4 glucose transporters was initially assessed during development of rats in cardiac muscle. To that end, membrane fractions and total RNA were purified from hearts during development, and transporter protein and mRNA content was determined. No significant differences were detected regarding the yield of membrane protein per gram of heart in 21-day fetuses $(9.2 \pm 2.1 \mathrm{mg}$ protein $/ \mathrm{g}$ tissue), 1 -day neonates $(12.3 \pm 1.9 \mathrm{mg}$ protein/g tissue), 10-day neonates $(10.2 \pm 2.4 \mathrm{mg}$ protein $/ \mathrm{g}$ tissue), 15 -day neonates $(11.1 \pm 1.7 \mathrm{mg}$ protein $/ \mathrm{g}$ tissue), or adults (13.6 $\pm 3.2 \mathrm{mg}$ protein $/ \mathrm{g}$ tissue). In contrast, a greater RNA yield was obtained in heart during fetal $(3.2 \pm 0.4 \mathrm{mg} / \mathrm{g}$ tissue) or early neonatal life $(2.5 \pm 0.2 \mathrm{mg} / \mathrm{g}$ tissue $)$ compared to the adult state $(1.2 \pm 0.1 \mathrm{mg} / \mathrm{g}$ tissue $)$.
GLUT-4 protein was assessed by Western blot using the specific monoclonal antibody $1 F 8$ (13). GLUT-4 protein was barely detectable in heart membrane fractions at days 19 and 20 of fetal life (Fig. 1), and a low expression was detected by day 21 (Fig. 1). Expression of GLUT-4 at day 21 of fetal life represents $13 \%$ of adult values. GLUT-4 increased after birth, becoming progressively more abundant and attaining adult levels after day 15 of post natal life (Fig. 1). No difference in GLUT-4 electrophoretic migration was detected throughout development.

The presence of GLUT- 4 mRNA was determined by Northern blot using a human cDNA probe under high stringency conditions. Thus, Northern analysis of brain tissue, which does not express GLUT-4 (13), did not reveal any labeling (data not shown). GLUT-4 mRNA levels were already detectable but low at day 17 of fetal life (Fig. 1) compared to the adult state ( $8 \%$ of adult levels). mRNA levels remained relatively low during early neonatal life (20\% of adult levels) (Fig. 1) and substantially increased after day 10 post natal (Fig. 1). At day 15 post natal, GLUT-4 mRNA levels were still markedly lower than in the adult heart in spite of the fact that no differences were delected at the level of GLUT-4 protein. As with GLUT-4 protein, no difference in electrophoretic migration of GLUT-4 mRNA was detected during development.

GLU'T-1 protein was assessed by Western blot using polyclonal antibody $\mathrm{Bb}$ against human erythrocyte glucose transporter, which does not cross-react with GLUT4 transporter (18). This antiserum recognizes, in Western blot, polypeptides other than GLUT-1, showing apparent mol wts greater than the glucose carrier. However, when GLUT-1 is initially immunoprecipitated using a C-terminal-specific monoclonal antibody (34), only the immunoprecipitate shows, by Western blot using antiserum $\mathrm{Bb}$, the band corresponding to GLUT-1 (data not shown). Therefore, this antiserum is useful to determine the expression of GLUT-1 protein. The expression of GLUT-1 glucose transporter protein was much greater in heart membrane extracts from days 19,20 , or 21 of fetal life (Fig. 2) compared to the adult group. In fact, GLUT-1 levels expressed in heart during the adult state only accounted for $2 \%$ of levels found during fetal life. However, soon after birth GLUT-1 protein initiated a rapid decrease, and GLUT-1 levels were already low after 6 days $(22 \%$ of fetal levels) and 10 days $(6 \%$ of fetal levels) of neonatal life (Fig. 2). Antibody $\mathrm{Bb}$ allows the detection of differences in electrophoretic mobility between GLUT-1 from rat brain and from cultured rat renal fibroblasts (data not shown). However, no difference in GLUT-1 electrophoretic migration was detected throughout development.

GLUT-1 mRNA levels in heart followed a similar 


\section{GLUT-4}

\section{PROTEIN}

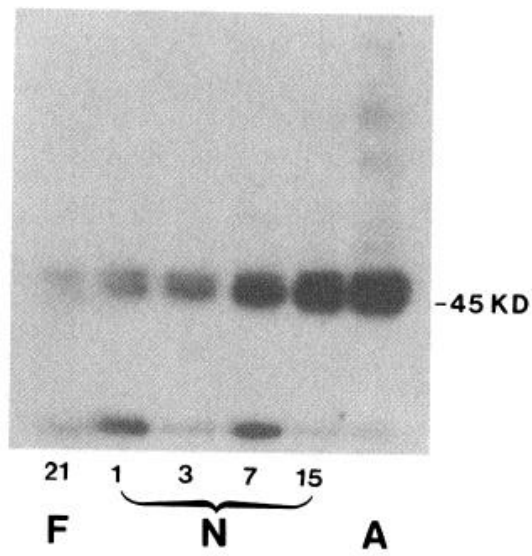

mRNA
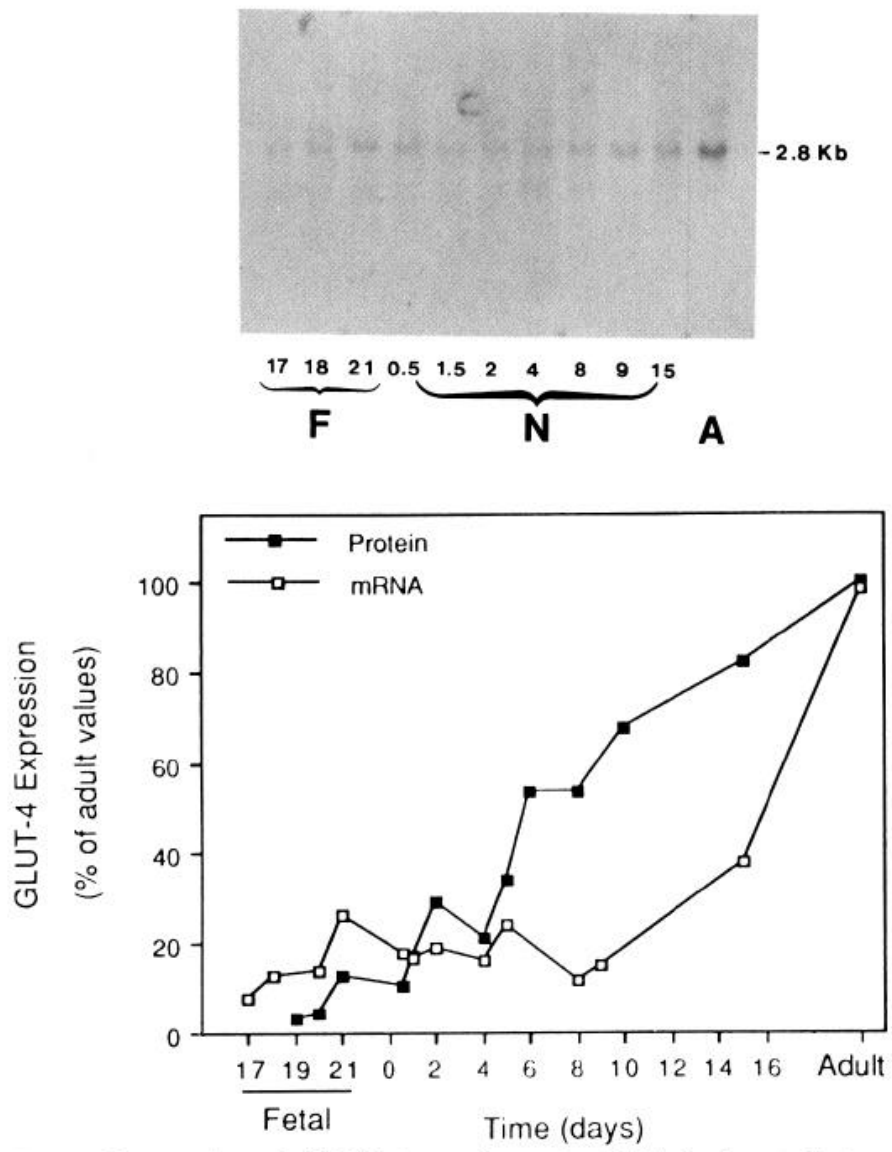

FIG. 1. Expression of GLUT-4 protein and mRNA in heart during development. Total RNA and membrane proteins were purified from pooled hearts obtained from rats (from day 19 of fetal life through 15 post natal and adult rats). Two hundred micrograms of membrane proteins or $15 \mu \mathrm{g}$ total RNA from the different experimental groups were applied on gels. After blotting, GLUT-4 protein (top panel) was detected by incubation with monoclonal antibody 1F8. GLUT-4 mRNA (middle panel) was detected after hybridization with a 2007-base pair SalI fragment as a cDNA probe (see Materials and Methods). Autoradiographs were subjected to scanning densitometry. The results of two to five separate experiments are shown and expressed as a percentage of adult values (bottom panel). SEMs ranged between $5-21 \%$ of mean values.

\section{GLUT-1}

\section{PROTEIN}

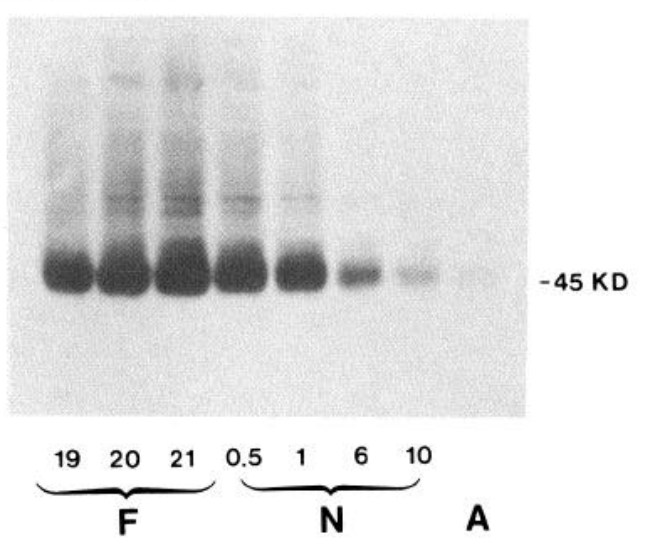

mRNA
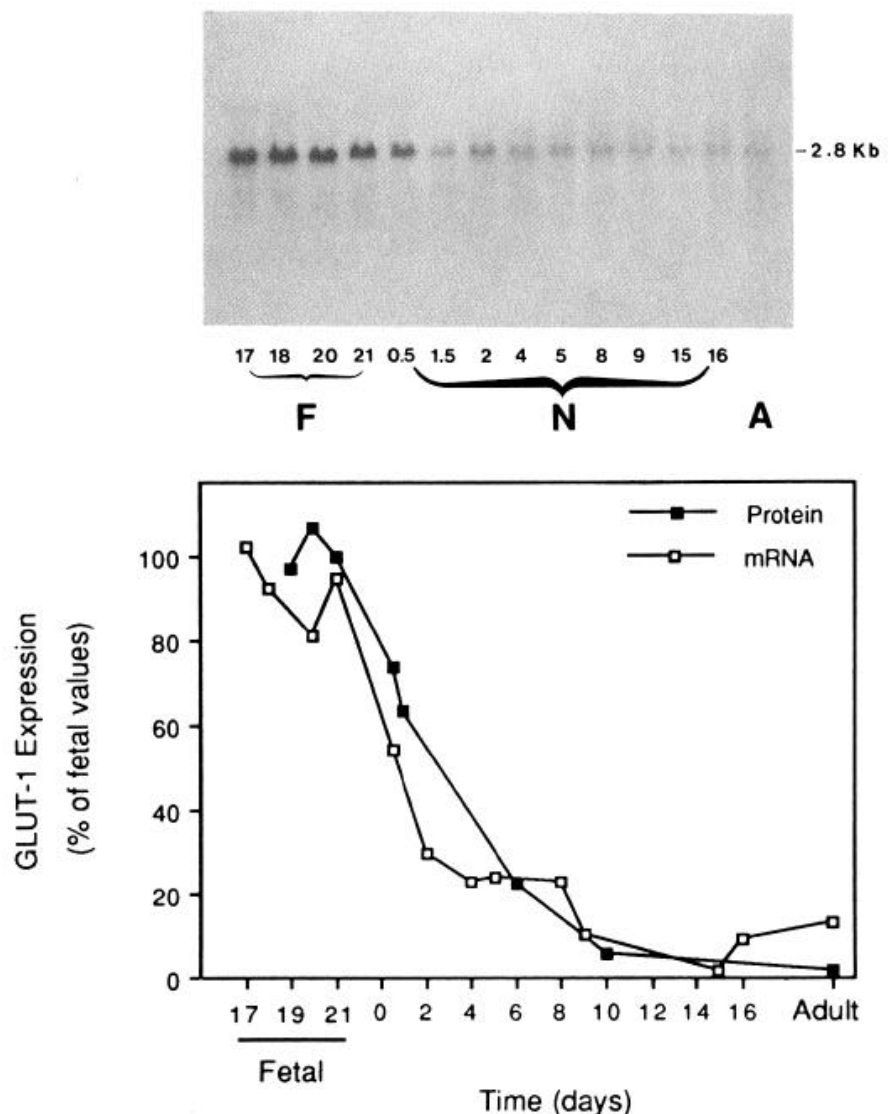

FIG. 2. Expression of GLUT-1 protein and mRNA in heart during development. Total RNA and membrane proteins were purified from pooled hearts obtained from rats (from day 19 of fetal life through 15 post natal and adult rats). One hundred micrograms of membrane proteins or $15 \mu \mathrm{g}$ total RNA from the different experimental groups were applied on gels. After blotting, GLUT-1 protein (top panel) was detected by incubation with antibody Bb. GLUT-1 mRNA (middle panel) was detected after hybridization with a 1346-base pair EcoRI fragment as a cDNA probe and as described in Materials and Methods. Autoradiographs were subjected to scanning densitometry. The results of one to two separate experiments are shown and expressed as a percentage of fetal (day 21) values (bottom panel). 
pattern to the GLUT-1 protein, being very high during fetal life and decreasing early post natal (Fig. 2).

\section{Expression of GLUT-4 and GLUT-1 protein in skeletal muscle during development}

In an attempt to define the existence of a general pattern, we next investigated the expression throughout development of GLUT-4 and GLUT-1 glucose transporters in skeletal muscle. To this end, membrane fractions were purified from hindlimb skeletal muscle. A low yield of membrane proteins was detected in 21-day fetuses $(2.7 \pm 0.6 \mathrm{mg}$ protein/g tissue), 1 -day neonates $(2.4$ $\pm 0.3 \mathrm{mg}$ protein $/ \mathrm{g}$ tissue $)$, and 5 -day neonates $(2.5 \pm 0.4$ $\mathrm{mg}$ protein/g tissue) compared to adult levels (5.2 \pm 0.7 $\mathrm{mg}$ protein/g tissue). Membrane protein yield increased progressively in 10 -day neonates $(3.8 \pm 0.5 \mathrm{mg}$ protein/ $\mathrm{g}$ tissue) and 15-day neonates $(4.1 \pm 0.8 \mathrm{mg}$ protein $/ \mathrm{g}$ tissue).

In keeping with the observations in heart, GLUT-4 protein was initially detected in skeletal muscle by day 21 of fetal life (Fig. 3). Expression of GLUT-4 at day 21 of fetal life was low and only accounted for $6 \%$ of adult values. In addition, GLUT-4 protein substantially increased soon after birth and attained adult levels at day 15 of neonatal life (Fig. 3). No differences in electrophoretic migration pattern was detected between GLUT-4 in preparations from adult and perinatal groups.

GLUT-1 protein also presented a very high expression level during fetal life in skeletal muscle (Fig. 3). Thus, GLUT-1 levels expressed in skeletal muscle during the adult state only accounted for $3 \%$ of levels found during fetal life (day 20 or day 21). Also in keeping with the pattern found in heart, GLUT-1 protein initiated a rapid decrease soon after birth, so GLUT-1 levels were low at day 3 post natal ( $20 \%$ of fetal levels). Protein levels comparable with the adult state were found by day 10 of neonatal life (Fig. 3).

\section{Expression of GLUT-4 and GLUT-1 protein in brown adipose tissue during development}

The developmental regulation of GLUT-4 and GLUT1 glucose transporter expression was also investigated in brown adipose tissue, an insulin-sensitive tissue that plays a critical thermogenic role in the newborn. To that end, membrane fractions were purified from interscapular brown adipose tissue. No difference in the yield of membrane proteins was detected in 21-day fetuses (19.8 $\pm 3.7 \mathrm{mg}$ protein $/ \mathrm{g}$ tissue) and 5-day neonates (14.9 \pm $1.8 \mathrm{mg}$ protein/g tissue) compared to adult levels (16.6 \pm $2.2 \mathrm{mg}$ protein/g tissue).

GLUT-4 protein was initially detected in brown adipose tissue by day 20 of fetal life ( $8 \%$ of adult levels) (Fig. 4), and expression of GLUT-4 by day 21 of fetal life accounted for $30 \%$ of adult values. Thus, GLUT- 4
$1 F 8$

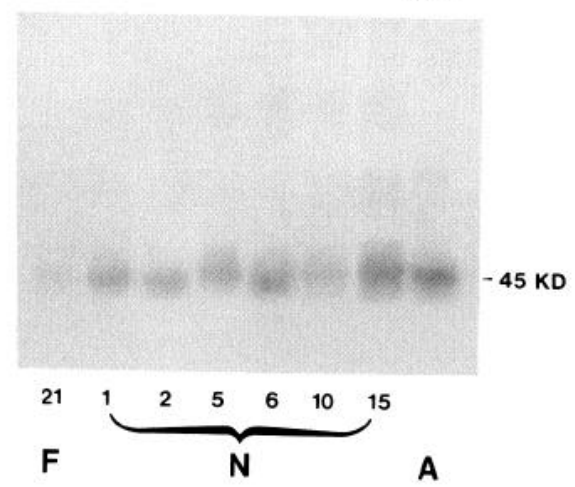

$\mathrm{Bb}$
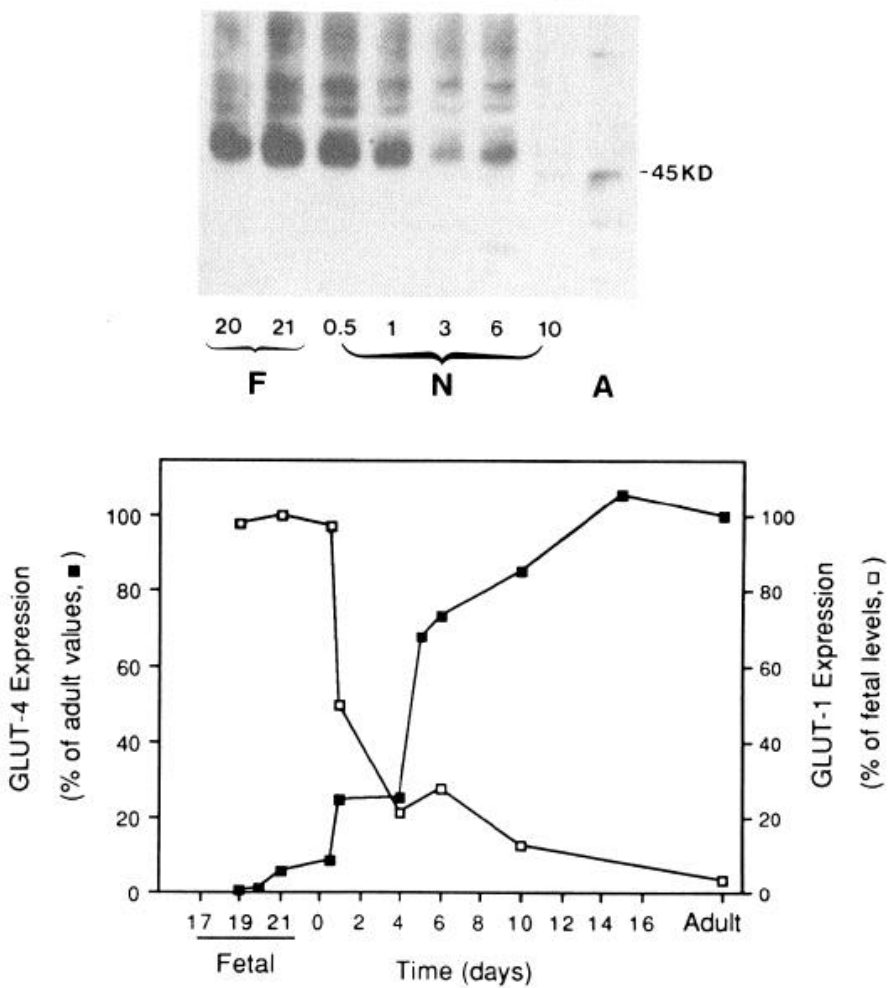

FIG. 3. Expression of GLUT-4 and GLUT-1 protein in skeletal muscle during development. Membranes were obtained from pooled hindlimb muscle from rats. Identical amounts of membrane proteins from the different experimental groups were applied on $10 \%$ acrylamide gels (200 $\mu \mathrm{g}$ for GLUT-4 and $100 \mu \mathrm{g}$ for GLUT-1). Protein from the gels was transferred to immobilon and immunoblotted with 1F8 (GLUT-4, top panel) or with $\mathrm{Bb}$ antiserum (GLUT-1, middle panel). Autoradiographs were subjected to scanning densitometry, and the results of three to five separate observations are shown (bottom panel). Data on GLUT-1 are expressed as a percentage of fetal (day 21) values, whereas data on GLUT-4 are expressed as a percentage of adult values.

protein in brown adipose tissue during fetal life was detected at high levels compared to the adult state. This represents a substantial difference between brown adipose tissue and heart and skeletal muscle. In addition, GLUT-4 protein substantially increased soon after birth, attaining adult levels between days 5-6 post natally (Fig. 


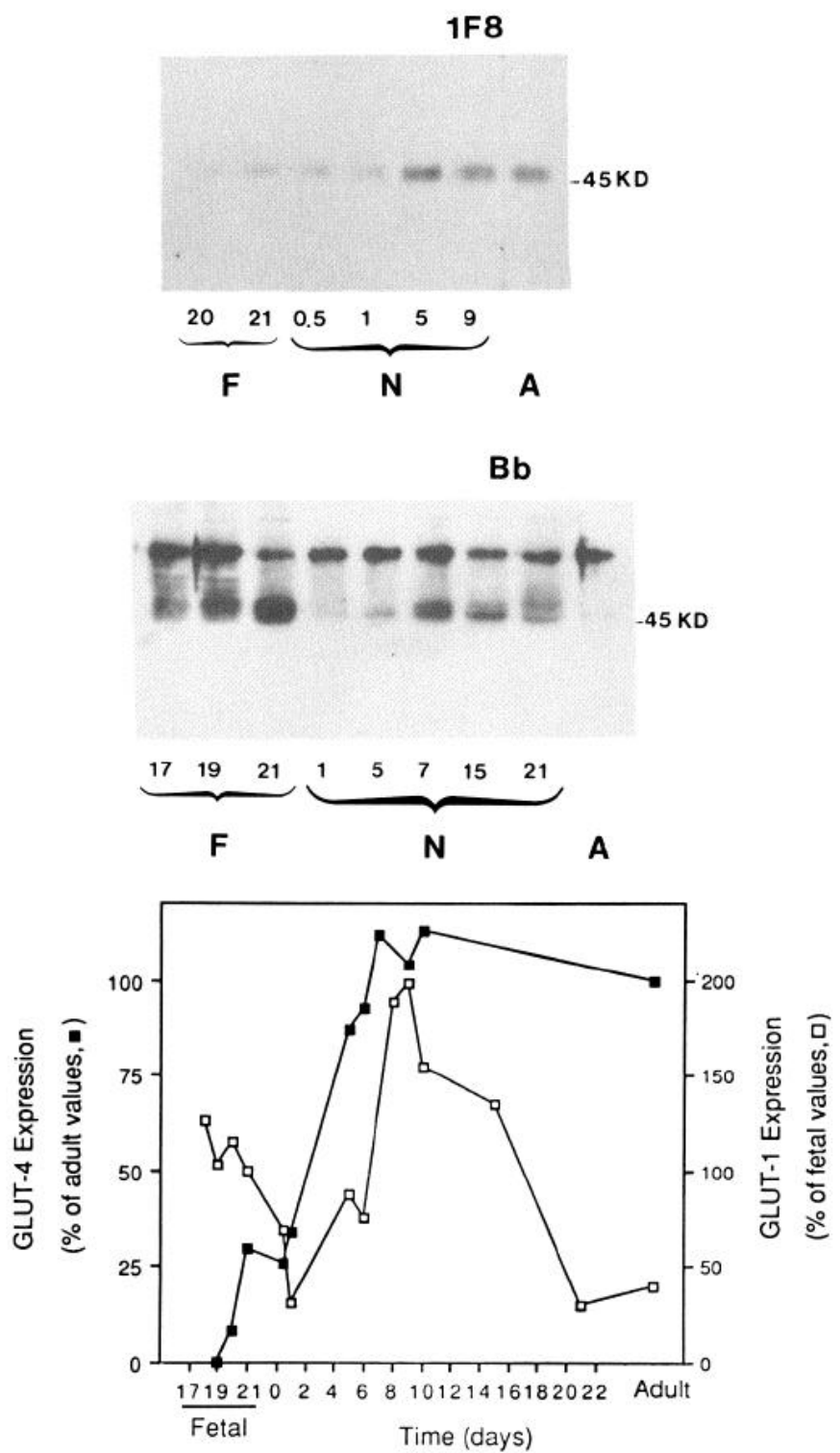

FIG. 4. Expression of GLUT-4 and GLUT-1 protein in brown adipose tissue during development. Membranes were obtained from pooled interscapular brown adipose tissue from rats. Identical amounts of membrane proteins from the different experimental groups were applied on $10 \%$ acrylamide gels $(200 \mu \mathrm{g}$ for GLUT-4 and $100 \mu \mathrm{g}$ for GLUT-1). Protein from the gels was transferred to immobilon and immunoblotted with 1F8 (GLUT-4, top panel) or with Bb antiserum (GLUT-1, middle panel). Autoradiographs were subjected to scanning densitometry, and the results of four to five separate observations are shown (bottom panel). Data on GLUT-1 are expressed as a percentage of fetal (day 21) values, whereas data on GLUT-4 are expressed as a percentage of adult values.

4). Thus, adult levels for GLUT-4 protein were reached earlier in brown adipose tissue than in heart and skeletal muscle (Figs. 1 and 3). GLUT-4 mRNA was detected at low levels during fetal life ( $5 \%$ of adult levels at day 19) and remained relatively low during early neonatal life (6\% of adult levels at day 1 post natal). GLUT- 4 mRNA levels were still markedly lower by days $6,9,13$, and 15 post natal compared to the adult brown adipose tissue (data not shown). At these times, no differences between neonatal and adult tissues had been detected at the level of GLUT-4 protein.

GLUT-1 protein was also highly expressed in brown adipose tissue during fetal life (Fig. 4), however, its developmental pattern was more complex than in heart or skeletal muscle. Thus, GLUT-1 levels diminished soon after birth (Fig. 4). This was followed by a rapid recovery period which led to a high expression level during days 8-15 post natal. Later on, GLUT-1 protein content decreased to adult control levels (Fig. 4). Adult levels accounted for $40 \%$ of fetal values.

\section{Effect of postmaturity on GLUT-1 and GLUT-4 expression in brown adipose tissue, heart, and skeletal muscle}

GLUT-4 and GLUT-1 proteins show an inverse pattern of changes in insulin-sensitive tissues in the perinatal period (Figs. 1-4); thus, whereas GLUT-1 rapidly decreases soon after birth, GLUT- 4 increases during that time. To determine whether these effects are a consequence of environmental changes associated with delivery, the effect of postmaturity was next investigated. To this end, pregnant rats were treated for 3 days with progesterone (from days 20-23), and GLUT-1 and GLUT-4 protein content was assessed in brown adipose tissue, skeletal, and cardiac muscle (Fig. 5).

The content of GLUT-1 protein was greater in the postmature group than in the control group (1-day post natal) in skeletal muscle and brown adipose tissue (Fig. 5). In skeletal muscle, GLUT-1 protein levels from postmature fetuses remained between levels detected in 21day-old fetuses and 1-day-old neonates (control group), indicating a partial protection by post maturity on GLUT-1 repression associated with early neonatal life. GLUT-1 protein in brown adipose tissue from the postmature group was similar to the levels detected in 21day normal fetuses (data not shown), evidence that post maturity totally prevented the decrease in GLUT-1 associated with early post natal life in brown adipose tissue.

Regarding GLUT-4 expression, no differences in protein content were detected in heart from control and postmature groups (Fig. 5). Furthermore, GLUT-4 protein was increased in skeletal muscle and brown adipose tissue as a result of progesterone-induced postmaturity (Fig. 5). In conclusion, GLUT-4 induction was never blocked by post maturity.

\section{Discussion}

In this study we have demonstrated the existence of a high expression of GLUT-1 glucose transporters in in- 
Bb

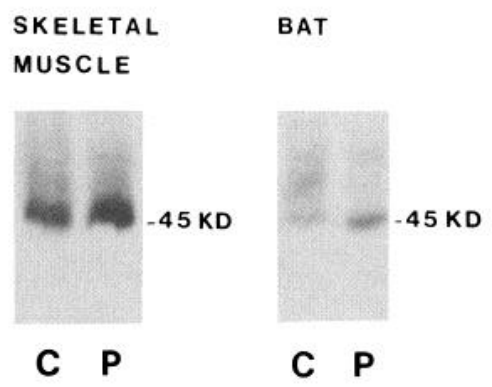

1F8

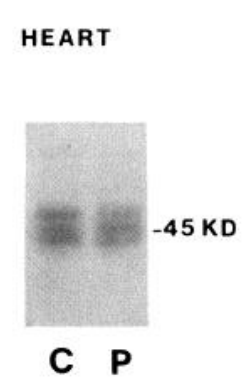

SKELETAL BAT MUSCLE
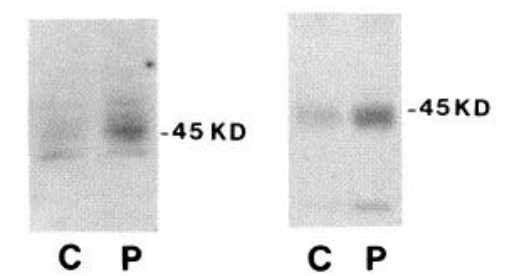

FIG. 5. Effect of post maturity on the expression of GLUT-1 and GLUT-4 protein in insulin-sensitive tissues. Postmature fetuses were obtained on day 23 from pregnant rats treated daily with $7 \mathrm{mg}$ progesterone (in ricine oil) from day 20 of pregnancy. Control rats received equal volumes of ricine oil and were studied 3 days later (day 1 post natal). Membranes were obtained from heart, hindlimb muscle, and interscapular brown adipose tissue from rats. Two hundred micrograms of membrane proteins from the different experimental groups were applied on gels. Protein from the gels was transferred to immobilon and immunoblotted with $\mathrm{Bb}$ antiserum to detect GLUT-1 (top panel) or antibody $1 \mathrm{~F} 8$ to visualize GLUT-4 (bottom panel). Autoradiographs were also subjected to scanning densitometry. The autoradiograms presented are representative from three separate observations.

sulin-sensitive tissues during fetal life in the virtual absence of GLUT- 4 carriers. Thus, we have found that GLUT-1 carriers in insulin-sensitive tissues are around 30 - to 50 -fold more abundant during fetal life than in adulthood in heart and skeletal muscle. GLUT- 3 mRNA levels were undetectable in heart tissue from 21-day-old fetuses and from neonates, under conditions in which expression was detected in some tissues from adult rats (Castelló, A., M. Furrias, M. Camps, X. Testar, M. Palacin, and A. Zorzano, unpublished results). A corollary of all these findings is that during fetal life, glucose uptake in peripheral tissues must be performed by GLUT-1 carriers. Bearing in mind the role of GLUT-1 on basal glucose uptake in isolated rat adipocytes (18), the high expression of GLUT-1 glucose transporters in peripheral tissues during fetal and early neonatal life explains the high rates of glucose uptake described in rat fetal heart (27) and in the incubated intact diaphragm during development (28).

It also should be mentioned that insulin causes stim- ulation of glucose uptake in fetal rat heart (27) and in diaphragm during early post natal life (28), that is, under conditions in which GLUT-4 is either absent or only scarce. These observations suggest that GLUT-1 is an insulin target during fetal life, which agrees with data obtained in several cell types $(18,35)$, but which is in contrast to data obtained in skeletal muscle from adult rats where insulin promotes translocation of GLUT-4 but not of GLUT-1 carriers (36). In any event, whether the effect of insulin during fetal life is related to carrier translocation as described in heart or skeletal muscle (37-39) or is a consequence of alterations in intrinsic activity of carriers remains to be determined.

The high expression of GLUT-1 during fetal life is common to heart, skeletal muscle, and brown adipose tissue, and all these tissues also undergo a decrease soon after birth which is protected, to a different extent, in postmature fetuses. Ontogenic studies performed in rat and rabbit brain also have shown that GLUT-1 protein and mRNA expression is high in fetal life, decreasing after birth (40-42). Furthermore, high GLUT-1 mRNA levels have been substantiated in rat lung, liver, and kidney during fetal life $(40,43)$ and they also rapidly diminish after birth. All these findings favor the existence of a circulating factor responsible for the enhanced expression of GLUT-1 during fetal life and which disappears rapidly after delivery but not in postmaturity.

In fetal heart, the high expression of GLUT-1 carriers is paralleled by high levels of GLUT-1 mRNA, suggesting the activation of a pretranslational step during fetal life. Whether the enhanced mRNA abundance is due to an increased rate of gene transcription or to an increased mRNA stability has not yet been determined.

Induction of GLUT-4 protein was detected by day 20 in brown adipose tissue ( $8 \%$ of adult values), and it was substantial by day 21 of gestation in brown adipose tissue ( $30 \%$ of adult values), heart ( $13 \%$ of adult values), and skeletal muscle $(6 \%$ of adult values). This induction occurred later than the onset of induction of mRNA levels which, at least in fetal heart, were already detectable by day 17 . After the onset of the expression in late pregnancy, all tissues investigated showed a progressive increase in GLUT-4 protein content, and this induction was not blocked by postmaturity. GLUT-4 protein levels increased up to adult values in all tissues investigated; however, adult levels were attained earlier in brown adipose tissue than in heart and skeletal muscle.

Recent observations have reported the localization of GLUT-4 glucose transporters in transverse tubule membranes in human skeletal muscle (44); in this regard, it is significant that the triads appear in rat skeletal muscle in significant numbers only post natally $(45,46)$, which coincides with the appearance of substantial GLUT-4 expression. Whether the expression of GLUT-4 and pro- 
tein components of transverse tubules is regulated during development with an identical time-dependence and by common regulatory factors deserves further study.

We have observed in rat heart and brown adipose tissue a dissociation between mRNA and protein regarding GLUT-4 expression during development. Thus, whereas GLUT-4 protein increases progressively during post natal life, attaining adult values at day 6 or day 10 , mRNA levels remain rather stable. This dissociation also has been reported for hepatic $\beta$-F1-ATPase in early post natal life (47), and it suggests the existence of GI.JT-4 regulation either at a translational level or to an increased stability of GLUT-4 protein during development. Based on our data, we propose two different phases in heart and brown adipose tissue during development: an initial phase characterized by modifications at a translational or posttranslational step for GLUT-4, and a later phase in which GLUT-4 mRNA increases and the prior modifications return to levels present in adult state.

The overall development pattern for GLU'T-4 and GLUT-1 in heart and skeletal muscle somewhat resembles the pattern previously described in $3 \mathrm{~T} 3$ adipocytes with differentiation $(48,49)$. Thus, when $3 \mathrm{~T} 3$ fibroblasts differentiate, GLUT-1 content decreases to some degree or remains unaltered, and GLUT-4 initiates its expression, and this is concomitant with a decrease in basal glucose uptake and an enhanced effect of insulin on glucose transport $(48,49)$. However, ontogenic development of muscle and adipose tissue broadly differ in quantitative terms from differentiation of $3 \mathrm{~T} 3$ cells. Thus, whereas differentiation of $3 \mathrm{~T} 3$ cells leads to variable changes on GLUT-1 expression-from $20-100 \%$ of levels found in fibroblasts $(48,49)$, rat adult tissues present GLUT-1 expression which is only about $2-3 \%$ of fetal levels. Furthermore, whereas in isolated rat adipocytes GLUT-4 represents more than $90 \%$ of total glucose carriers (18), in 3T3-L1 adipocytes GLUT-1 and GLUT-4 are present at a 3:1 molar ratio (50).

In the present study, we have reported the triggering of GLUT-4 induction and GLUT-1 repression during perinatal life. 'These two events seem to differ in various aspects: 1) whereas the mechanisms for GLUT-1 repression seem to be at a pretranslational level, the onset of GLUT-4 induction is dependent on translational or posttranslational activation; 2) the timing of the two events is different, the onset of GLUT-4 mRNA induction being earlier than the repression of GLUT-1; and 3) whereas GLUT-1 repression is inhibited by post maturity, GLUT-4 protein induction is not blocked. All these findings strongly suggest that the two events are mediated by different mechanisms.

The nature of the signals involved in the onset of GLUT-4 expression and GLUT-1 repression is unknown. Insulin might be involved in the regulation of glucose transporter expression during perinatal life. In this regard, it should be pointed out that circulating insulin rises to high concentrations over the last 3 days of gestation in the rat, decreasing to low levels during early post natal development (51-54) and there is a substantial expression of insulin receptors, displaying high affinity binding sites, in rat fetal skeletal muscle (55). Regarding neural activity, it has been reported that sympathetic innervation is functionally active in rat muscle and brown adipose tissue near term (56-58) and also might be proposed as a modulator of glucose carrier expression. At present, studies are being conducted to test the participation of insulin or neural activity on the developmental regulation of GLUT-1 and GLUT-4 expression in insulin-sensitive tissues.

\section{Acknowledgments}

We thank Robin Rycroft for his editorial help.

\section{References}

1. Mueckler M, Caruso C, Baldwin SA, Panico M, Blemch I, Morris HR, Allard WJ, Lienhard GE, Lodish HF 1985 Sequence and structure of a human glucose transporter. Science 229:941-945

2. Birnbaum MJ, Haspel HC, Rosen UM 1986 Cloning and characterization of a cDNA encoding the rat brain glucose-transporter protein. Proc Natl Acad Sci USA 83:5784-5788

3. Thorens B, Sarkar HK, Kaback HR, Lodish HF 1988 Cloning and functional expression in bacteria of a novel glucose transporter present in liver, intestine, kidney and $\beta$-pancreatic islet cells. Cell 55:281-290

4. Kayano T, Fukumoto H, Eddy RL, Fan Y-S, Byers MG, Shows TB, Bell GI 1988 Evidence for a family of human glucose transporter-like proteins. J Biol Chem 263:15245-15248

5. Fukumoto H, Seino S, Imura H, Seino Y, Eddy RL, Fukushima Y, Byers MG, Shows ' $\mathrm{I} B$, Bell GI 1988 Sequence, tissue distribution, and chromosomal localization of mRNA encoding a human glucose transporter-like protein. Proc Natl Acad Sci USA 85:5434-5438

6. James DE, Strube M, Mueckler M 1989 Molecular cloning and characterization of an insulin-regulatable glucose transporter. $\mathrm{Na}$ ture 338:83-87

7. Charron MJ, Brosius III FC, Alper SL, Lodish HF 1989 A glucose transport protein expressed predominately in insulin-responsive tissues. Proc Natl Acad Sci USA 86:2535-2539

8. Birnbaum MJ 1989 Identification of a novel gene encoding an insulin-responsive glucose transporter protein. Cell 57:305-315

9. Fukumoto H, Kayano T, Buse JB, Edwards Y, Pilch PF, Bell GI, Seino S 1989 Cloning and characterization of the major insulinresponsive glucose transporter expressed in human skeletal muscle and other insulin-responsive tissues. J Biol Chem 264:7776-7779

10. Kaestner KH, Christy RJ, McLenithan JC, Braiterman LT, Cornelius P, Pekala PH, Lane MD 1989 Sequence, tissue distribution, and differential expression of mRNA for a putative insulin-responsive glucose transporter in mouse 3T3-L1 adipocytes. Proc Natl Acad Sci USA 86:3150-3154

11. Kayano T, Burant CF, Fukumoto H, Gould GW, Fan Y-S, Eddy RL, Byers MG, Shows TB, Seino S, Bell GI 1990 Human facilitative glucose transporters. Isolation, functional characterization, and gene localization of cDNAs encoding an isoform (GLUT5) expressed in small intestine, kidney, muscle and adipose tissue and an unusual glucose transporter pseudogene-like sequence (GLUT6). J Biol Chem 265:13276-13282

12. Flier JS, Mueckler M, McCall AL, Lodish HF 1987 Distribution of glucose transporter messenger RNA transcripts in tissues of rat 
and human. J Clin Invest 79:657-661

13. James DE, Brown R, Navarro J, Pilch PF 1988 Insulin-regulatable tissues express a unique insulin-sensitive glucose transporter protein. Nature 333:183-185

14. Keller K, Strube M, Mueckler M 1989 Functional expression of the human HepG2 and rat adipocyte glucose transporters in Xenopus oocytes. Comparison of kinetic parameters. J Biol Chem 264:18884-18889

15. Wang C 1987 The D-glucose transporter is tissue-specific. Skeletal muscle and adipose tissue have a unique form of glucose transporter. J Biol Chem 262:15689-15695

16. Oka Y, Asano T, Shibasaki Y, Kasuga M, Kanazawa Y, Takaku F 1988 Studies with antipeptide antibody suggest the presence of at least two types of glucose transporter in rat brain and adipocyte. $\mathrm{J}$ Biol Chem 263:13432-13439

17. Vilaró S, Palacín M, Pilch PF, Testar X, Zorzano A 1989 Expression of an insulin-regulatable glucose carrier in muscle and fat endothelial cells. Nature 342:798-800

18. Zorzano A, Wilkinson W, Kotliar N, Thoidis G, Wadzinkski BE, Ruoho AE, Pilch PF 1989 Insulin-regulated glucose uptake in rat adipocytes is mediated by two transporter isoforms present in at least two vesicle populations. J Biol Chem 264:12358-12363

19. Berger J, Biswas C, Vicario PP, Strout HV, Saperstein R, Pilch PF 1989 Decreased expression of the insulin-responsive glucose transporter in diabetes and fasting. Nature 340:70-72

20. Sivitz WI, DeSautel SL, Kayano T, Bell GI, Pessin JE 1989 Regulation of glucose transporter messenger RNA in insulin-deficient states. Nature 340:72-74

21. Garvey WT, Huecksteadt TP, Birnbaum MJ 1989 Pretranslational suppression of an insulin-responsive glucose transporter in rats with diabetes mellitus. Science 245:60-63

22. Kahn BB, Charron MJ, Lodish HF, Cushman SW, Flier JS 1989 Differential regulation of two glucose transporters in adipose cells from diabetic and insulin-treated diabetic rats. J Clin Invest $84: 404-411$

23. Karnieli E, Hissin PJ, Simpson IA, Salans LB, Cushman SW 1981 A possible mechanism of insulin resistance in the rat adipose cell in streptozotocin-induced diabetes mellitus. Depletion of intracellular glucose transport systems. J Clin Invest 68:811-814

24. Garvey WT, Huecksteadt TP, Matthaei S, Olefsky JM 1987 Role of glucose transporters in the cellular insulin resistance of type II non-insulin dependent diabetes mellitus. J Clin Invest 81:15281536

25. Olefsky JM 1976 Effects of fasting on insulin binding, glucose transport and glucose oxidation in isolated rat adipocytes. $J$ Clin Invest 58:1450-1460

26. Kahn CR, Simpson IA, Cushman SW 1988 Divergent mechanisms for the insulin resistant and hyperresponsive glucose transport in adipose cells from fasted and refed rats: alterations in both glucose transporter number and intrinsic activity. J Clin Invest 82:691699

27. Clark Jr CM 1971 Carbohydrate metabolism in the isolated fetal rat heart. Am J Physiol 220:583-588

29. Wang C 1985 Insulin-stimulated glucose uptake in rat diaphragm during post natal development: lack of correlation with the number of insulin receptors and of intracellular glucose transporters. Proc Natl Acad Sci USA 82:3621-3625

29. Ramirez I, Llobera M, Herrera E 1983 Circulating triacylglycerols, lipoproteins, and tissue lipoprotein lipase activities in rat mothers and offspring during the perinatal period: effect of postmaturity. Metabolism 32:333-341

30. Bradford MM 1976 A rapid and sensitive method for the quantitation of microgram quantities of protein utilizing the principle of protein-dye binding. Anal Biochem 72:248-254

31. Laemmli UK 1970 Cleavage of structural proteins during the assembly of the head of bacteriophage T4. Nature 227:680-685

32. Chomczynski P, Sacchi N 1987 Single-step method of RNA isolation by acid guanidium thiocyanate-phenol-chloroform extraction. Anal Biochem 162:156-159

33. Rosen KM, Villa-Komaroff L 1990 An alternative method for the visualization of RNA in formaldehyde agarose gels. Focus 12:2324

34. Andersson L, Lundahl P 1988 C-terminal-specific monoclonal antibodies against the human red cell glucose transporter. Epitope localization with synthetic peptides. J Biol Chem 263:11414-11420

35. Blok J, Gibbs EM, Lienhard GE, Slot JW, Geuze HJ 1988 Insulininduced translocation of glucose transporters from post-Golgi compartments to the plasma membrane of 3T3-L1 adipocytes. J Cell Biol 106:69-76

36. Douen AG, Ramlal T, Rastogi S, Bilan PJ, Cartee GD, Vranic M, Holloszy JO, Klip A 1990 Exercise induces recruitment of the insulin-responsive glucose transporter. Evidence for distinct intracellular insulin and exercise-recruitable transporter pools in skeletal muscle. J Biol Chem 265:13427-13430

37. Watanabe T, Smith MM, Robinson FW, Kono T 1984 Insulin action on glucose transport in cardiac muscle. J Biol Chem 259:13117-13122

38. Klip A, Ramlal T, Young DA, Holloszy JO 1987 Insulin-induced translocation of glucose transporters in rat hindlimb muscles. FEBS Lett 224:224-230

39. Zaninetti D, Greco-Perotto R, Assimacopoulos-Jeannet F, Jeanrenaud B 1988 Effects of insulin on glucose transport and glucose transporters in rat heart. Biochem J 250:277-283

40. Asano T, Shibasaki Y, Kasuga M, Kanazawa Y, Takaku F, Akanuma Y, Oka Y 1988 Cloning of a rabbit brain glucose transporter cDNA and alteration of glucose transporter mRNA during tissue development. Biochem Biophys Res Commun 154:1204-1211

42. Sivitz W, DeSautel S, Walker PS, Pessin JE 1989 Regulation of the glucose transporter in developing rat brain. Endocrinology 124:1875-1880

42. Sadiq F, Holtzclaw L, Chundu K, Muzzafar A, Devaskar S 1990 The ontogeny of the rabbit brain glucose transporter. Endocrinology 126:2417-2424

43. Werner H, Adamo M, Lowe Jr WL, Roberts CT, LeRoith D 1989 Developmental regulation of rat brain/Hep G2 glucose transporter gene expression. Mol Endocrinol 3:273-279

44. Friedman JE, Dudek RW, Whitehead DS, Downes DL, Frisell WR, Caro JF, Dohm GL 1991 Immunolocalization of glucose transporter GLUT4 within human skeletal muscle. Diabetes 40:150-154

45. Schiaffino S, Margreth A 1969 Coordinated development of the sarcoplamic reticulum and $\mathrm{T}$-system during post natal differentiation of rat skeletal muscle. J Cell Biol 41:855-875

46. Walker SM, Schrodt GR 1968 Triads in skeletal muscle fibers of 19-day fetal rats. J Cell Biol 37:564-569

47. Izquierdo JM, Luis AM, Cuezva JM 1990 Postnatal mitochondrial differentiation in rat liver. Regulation by thyroid hormones of the $\beta$-subunit of the mitochondrial F1-ATPase complex. J Biol Chem 265:9090-9097

48. Tordjman KM, Leingang KA, James DE, Mueckler MM 1989 Differential regulation of two distinct glucose transporter species in 3T3-L1 adipocytes: effect of chronic insulin and tolbutamide treatment. Proc Natl Acad Sci USA 86:7761-7765

49. Garcia de Herreros A, Birnbaum MJ 1989 The acquisition of increased insulin-responsive hexose transport in 3T3-L1 adipocytes correlates with expression of a novel transporter gene. J Biol Chem 264:19994-19999

50. Calderhead DM, Kitagawa K, Tanner LI, Holman GD, Lienhard G 1990 Insulin regulation of the two glucose transporters in 3T3$\mathrm{L} 1$ adipocytes. J Biol Chem 265:13800-13808

51. Sodoyez-Goffaux FR, Sodoyez JC, De Vos CJ 1979 Insulin secretion and metabolism during the perinatal period in the rat. Evidence for a placental role in fetal hyperinsulinemia. J Clin Invest 63:1095-1102

52. Watts C, Gain KR, Sandin PL 1976 Glucose homeostasis in the developing rat. I. Blood glucose and immunoreactive insulin in the later stages of gestation of the fetal rat. Biol Neonate 30:88-94

53. Cuezva JM, Burkett ES, Kerr DS, Rodman HM, Patel MS 1982 The newborn of diabetic rat. I. Hormonal and metabolic changes in the post natal period. Pediatr Res 16:632-637

54. Blázquez E, Montoya E, López-Quijada C 1970 Relationship be- 
tween insulin concentrations in plasma and pancreas of foetal and weanling rats. $J$ Endocrinol 48:553-561

55. Alexandrides T, Moses AC, Smith RJ 1989 Developmental expression of receptors for insulin, insulin-like growth factor I, and insulin-like growth factor II in rat skeletal muscle. Endocrinology 124:1064-1076

56. Nedergaard J, Connolly E, Cannon B 1986 Brown adipose tissue in the mammalian neonate. In Trayhurn P, Nicholls DG (eds)
Brown adipose tissue. Edward Arnold Publ, London, pp 152-213

57. DeChamplain J, Malmfors T, Olson L, Sachs CH 1970 Ontogenesis of peripheral adrenergic neurons in the rat: pre- and post natal observations. Acta Physiol Scand 80:267-288

58. Pappano AJ 1977 Ontogenetic development of autonomic neuroeffector transmission and transmitter reactivity in embryonic and fetal hearts. Pharmacol Rev 29:3-33

\section{First Asian and Oceanic Congress of Andrology November 9-12, 1992, Nanjing, China}

\section{Organizing Committee}

Advisory Board: Chairman, Jie-Ping Wu; Vice-Chairman, E. Diczfalusy; Members, C. W. Bardin, D. M. de Kretser, N. R. Kalla, F. A. Leidenberger, G. M. H. Waites, and C. C. L. Wang.

Congress Chairmen and Secretaries: Chairman, Shao-Zhen Qian; Vice-Chairpersons, Zhi-Ping Gu, Ying-Lu Guo, Yu Jiang, Shun-Qiang Li, Yi-Fei Wang, and Gui-Yuan Zhang; Secretary-General, YouGuang Xu; Deputy Secretaries-General, Ping-Zhi Huang and Jian-Wei Zhang.

Scientific Program Committee: Chairman, H. W. G. Baker; Vice-Chairman, P. Y. D. Wong; Members, F. X. A. Adimoelja, H. Y. Lee, Shao-Zhen Qian, A. R. Sheth, and Hitoshi Takihara.

Congress Organizers: Jiangsu Province Science and Technology Exchange Centre with Foreign Countries (JSTEC), Jiangsu Family Planning Institute, and Jiangsu Family Planning Research Association.

\section{For Information}

Postal address: Secretariat of First Asian and Oceanic Congress of Andrology, c/o JSTEC, 39 East Beijing Road, Nanjing 210008, People's Republic of China; phone, 086-25-635407; Fax, 086-25-714369; telex, 342215 STEC CN. 